\title{
Photochemical carbon dioxide reduction with metal complexes
}

\author{
Etsuko Fujita* \\ Chemistry Department, Brookhaven National Laboratory, Upton, NY 11973-5000, USA
}

Received 9 June 1998; received in revised form 30 November 1998

\section{Contents}

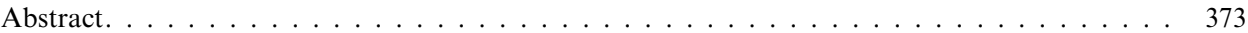

1. Introduction . . . . . . . . . . . . . . . . . . . . . . . . . . . . . . . 374

2. Photocatalytic $\mathrm{CO}_{2}$ reduction . . . . . . . . . . . . . . . . . . . . 374

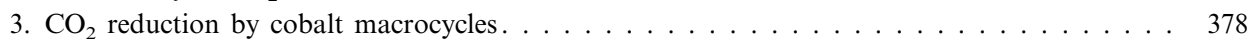

4. $\mathrm{CO}_{2}$ reduction by $\left[\mathrm{Ru}(\mathrm{bpy})_{2}(\mathrm{CO}) \mathrm{X}\right]^{n+}(\mathrm{X}=\mathrm{CO}, \mathrm{Cl}$, and $\mathrm{H}) \ldots \ldots \ldots \ldots$

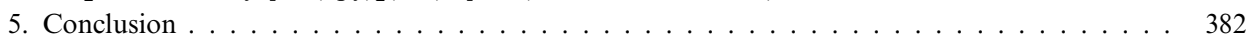

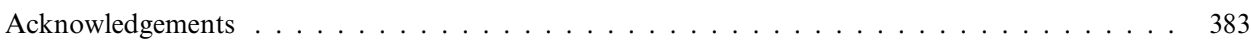

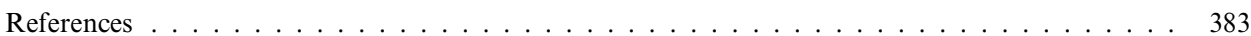

\section{Abstract}

Transition-metal complexes, $\mathrm{CoHMD}^{2}+(\mathrm{HMD}=5,7,7,12,14,14$-hexamethyl-1,4,8,11-tetraazacyclotetradeca-4,11-diene) and $\mathrm{Ru}(\mathrm{bpy})_{2}(\mathrm{CO}) \mathrm{X}^{n+}\left(\mathrm{bpy}=2,2^{\prime}\right.$-bipyridine, $\mathrm{X}=\mathrm{CO}, \mathrm{Cl}$, $\mathrm{H}$, etc.), mediate electron transfer in the photochemical reduction of $\mathrm{CO}_{2}$. The thermodynamics and kinetics of $\mathrm{CO}_{2}$ binding to $\mathrm{CoHMD}{ }^{+}$, and spectroscopic characterization of the $\mathrm{CO}_{2}$ adducts of $\mathrm{CoHMD}^{+}$and $\left[\mathrm{Ru}^{\mathrm{I}}(\mathrm{bpy})\left(\mathrm{bpy}^{-}\right)(\mathrm{CO})\right]$ are described. (C) 1999 Elsevier Science S.A. All rights reserved.

Keywords: Carbon dioxide reduction; Small molecule activation; Photocatalysis; Carboxylates; Macrocycles; Diimine

* Tel.: + 1-516-344-4356; fax: + 1-516-344-5815.

E-mail address: fujita@bnl.gov (E. Fujita)

0010-8545/99/\$ - see front matter (C) 1999 Elsevier Science S.A. All rights reserved.

PII: S0010-8545(99)00023-5 


\section{Introduction}

The reduction of carbon dioxide to produce carbon monoxide, formic acid or methanol is an important area relevant to the solution of problems related to global warming and the depletion of fossil fuels [1]. Photochemical carbon dioxide reduction poses a number of difficult scientific challenges. Because of the stability of carbon dioxide, energy is needed to drive the desired transformations; moreover, its inertness necessitates the use of catalysts. Transition-metal complexes are used as catalysts since they can absorb a significant part of the solar spectrum, have long-lived excited states, and can promote the activation of small molecules. Here we summarize earlier studies on photochemical $\mathrm{CO}_{2}$ reduction and present our recent results on the characterization of intermediates such as the $\mathrm{CO}_{2}$ adduct, and the kinetics and mechanisms of photochemical and electrochemical $\mathrm{CO}_{2}$ reduction with cobalt macrocycles and $\mathrm{Ru}(\mathrm{bpy})_{2}(\mathrm{CO}) \mathrm{X}^{n+}$ complexes $\left(\mathrm{bpy}=2,2^{\prime}\right.$-bipyridine, $\mathrm{X}=\mathrm{CO}, \mathrm{Cl}, \mathrm{H}$, etc.). The results are obtained using a variety of techniques including UV-vis, NMR, FT-IR spectroscopy, flash photolysis, pulse radiolysis, $\mathrm{X}$-ray structure determinations, electrochemistry, XANES and EXAFS.

\section{Photocatalytic $\mathrm{CO}_{2}$ reduction}

The potential for the reduction of $\mathrm{CO}_{2}$ to $\mathrm{CO}_{2}^{-}$is $-1.9 \mathrm{~V}$ versus NHE, making the one-electron reduction highly unfavorable. In addition, there is a large kinetic 'overvoltage' for the one-electron reduction because of structural differences between linear $\mathrm{CO}_{2}$ and bent $\mathrm{CO}_{2}^{-}$. In contrast, proton-assisted multielectron steps are much more favorable as shown below (at $\mathrm{pH} 7$ in aqueous solution versus NHE) [2,3]:

$$
\begin{aligned}
& \mathrm{CO}_{2}+2 \mathrm{H}^{+}+2 \mathrm{e}^{-} \rightarrow \mathrm{HCO}_{2} \mathrm{H} \quad E^{\circ}=-0.61 \mathrm{~V} \\
& \mathrm{CO}_{2}+2 \mathrm{H}^{+}+2 \mathrm{e}^{-} \rightarrow \mathrm{CO}+\mathrm{H}_{2} \mathrm{O} \quad E^{\circ}=-0.53 \mathrm{~V} \\
& \mathrm{CO}_{2}+4 \mathrm{H}^{+}+4 \mathrm{e}^{-} \rightarrow \mathrm{C}+2 \mathrm{H}_{2} \mathrm{O} \quad E^{\circ}=-0.20 \mathrm{~V} \\
& \mathrm{CO}_{2}+4 \mathrm{H}^{+}+4 \mathrm{e}^{-} \rightarrow \mathrm{HCHO}+\mathrm{H}_{2} \mathrm{O} \quad E^{\circ}=-0.48 \mathrm{~V} \\
& \mathrm{CO}_{2}+6 \mathrm{H}^{+}+6 \mathrm{e}^{-} \rightarrow \mathrm{CH}_{3} \mathrm{OH}+\mathrm{H}_{2} \mathrm{O} \quad E^{\circ}=-0.38 \mathrm{~V} \\
& \mathrm{CO}_{2}+8 \mathrm{H}^{+}+8 \mathrm{e}^{-} \rightarrow \mathrm{CH}_{4}+2 \mathrm{H}_{2} \mathrm{O} \quad E^{\circ}=-0.24 \mathrm{~V}
\end{aligned}
$$

Since the two-electron reduction to formic acid or $\mathrm{CO}$ requires a considerably lower potential than the one-electron reduction, electrolysis in the presence of catalysts can be carried out at considerably lower voltages. In the photochemical reduction of $\mathrm{CO}_{2}$, the same considerations apply: the one-electron reduction to $\mathrm{CO}_{2}^{-}$requires extremely strong reducing agents that are generally difficult to produce by photochemical methods.

Table 1 summerizes the results from a large number of photoreduction studies of $\mathrm{CO}_{2}$ by homogeneous and microheterogeneous photocatalysts. Although many 
Table 1

Photocatalytic Reduction of $\mathrm{CO}_{2}{ }^{\mathrm{a}}$

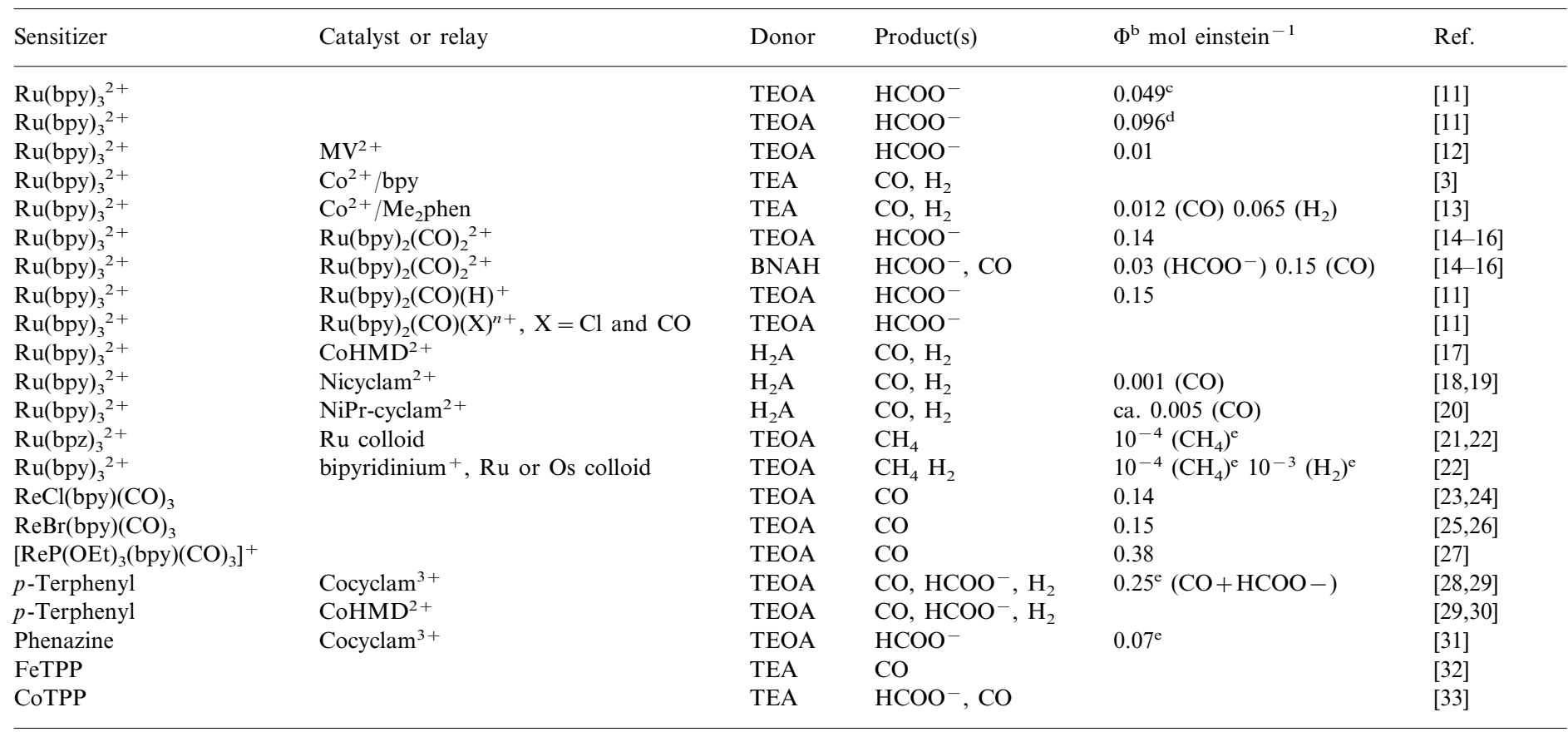

a Abbreviations used: TEOA $=$ triethanolamine, $\mathrm{MV}^{2+}=$ methylviologen, $\mathrm{TEA}=$ triethylamine, bpy $=2,2^{\prime}$-bipyridine, $\mathrm{Me}_{2}$ phen $=2,9-\mathrm{Dimethyl}-1,10-$ phenanthroline, BNAH=1-benzyl-1,4-dihydronicotinamide, $\mathrm{H}_{2} \mathrm{~A}=$ ascorbic acid, cyclam $=1,4,8,11$-tetraazacyclotetradecane and Pr-cyclam $=6-((\mathrm{N}-$ R)pyridin-4-yl)methyl-1,4,8,11-tetraazacyclotetradecane where $\mathrm{R}=p$-methoxybenzyl and benzyl, TPP $=5,10,15,20$-tetraphenyl-21H,23H-porphine

${ }^{\mathrm{b}}$ Unless otherwise noted, the quantum yield of product formation is defined as the formation rate divided by the light intensity.

${ }^{\mathrm{c}}$ With $15 \%$ water in DMF.

${ }^{\mathrm{d}}$ With $15 \%$ water and excess bpy in DMF.

e Assuming two (or eight) photons produce one molecule of the product. 
photoinduced stoichiometric reactions such as an insertion or addition of $\mathrm{CO}_{2}$, reductive disproportionation to $\mathrm{CO}$, metathesis of $\mathrm{CN}$ by $\mathrm{CO}_{2}$, the formation of $\mathrm{M}-\mathrm{CO}$ and $\mathrm{M}-\mathrm{OCHO}$ complexes and, in rare cases, the formation of $\mathrm{M}=\mathrm{O}$ together with $\mathrm{CO}$ are known [1,4-8], we limit our discussion to photocatalytic reactions using metal complexes as catalysts. Photoinduced $\mathrm{CO}_{2}$ fixation systems containing enzymes are omitted $[9,10]$.

The systems used for photochemical $\mathrm{CO}_{2}$ reduction studies can be divided into several groups: (1) $\mathrm{Ru}(\mathrm{bpy})_{3}{ }^{2+}$ both as a photosensitizer and a catalyst; (2) $\mathrm{Ru}(\mathrm{bpy})_{3}{ }^{2+}$ as a photosensitizer and another metal complex as a catalyst; (3) $\mathrm{Ru}(\mathrm{bpy})_{3}{ }^{2+}$ and $\mathrm{Ru}(\mathrm{bpy})_{3}{ }^{2+}$-type complexes as photosensitizers in microheterogeneous systems; (4) $\operatorname{ReX}(\mathrm{CO})_{3}$ (bpy) or a similar complex both as a photosensitizer and a catalyst; (5) porphyrins both as photosensitizer and catalyst; and (6) organic photosensitizers and a metal complex as catalysts. We are particularly interested in photochemical $\mathrm{CO}_{2}$ reduction with cobalt macrocycles and $\mathrm{Ru}(\mathrm{bpy})_{2}(\mathrm{CO}) \mathrm{X}^{n+}$ (bpy $=2,2^{\prime}$-bipyridine, $\mathrm{X}=\mathrm{CO}, \mathrm{Cl}, \mathrm{H}$, etc.) as catalysts in categories (2) and (6).

Photochemical $\mathrm{CO}_{2}$ reduction to $\mathrm{CO}$ (and formate in some cases) has been reported in a catalytic system using $\mathrm{Ru}(\mathrm{bpy})_{3}{ }^{2+}$ as the sensitizer, CoHMD ${ }^{2+}$ $(\mathrm{HMD}=5,7,7,12,14,14$-hexamethyl-1,4,8,11-tetraazacyclotetradeca-4,11-diene, see Scheme 1) as the electron relay catalyst, and ascorbate as a sacrificial reductive quencher [17]. These systems also produce $\mathrm{H}_{2}$ via reduction of water. When $\mathrm{CoHMD}^{2+}$ is used as a catalyst at $\mathrm{pH} 4$, the system produces a mixture of $\mathrm{CO}$ and $\mathrm{H}_{2}$ with low selectivity $\left(\mathrm{CO} / \mathrm{H}_{2}=0.06-0.3\right.$, depending on the conditions). $\left[\mathrm{Co}^{\mathrm{III}} \mathrm{HMD}\left(\mathrm{H}^{-}\right)\right]^{2+}$, which forms by protonation of $\mathrm{Co}^{\mathrm{I}} \mathrm{HMD}^{+}$, has been suggested to be a common intermediate $[17,34]$ for $\mathrm{CO}$ and $\mathrm{H}_{2}$ production in the photocatalytic system, however, new studies [30] indicate that this may be incorrect (see Section 3).

DMF solutions containing $\mathrm{Ru}(\mathrm{bpy})_{3}{ }^{2+}, \mathrm{Ru}(\mathrm{bpy})_{2}(\mathrm{CO}) \mathrm{X}^{n+}(\mathrm{X}=\mathrm{CO}, \mathrm{Cl}, \mathrm{H}$, etc.), and TEOA as an electron donor have been used for photochemical $\mathrm{CO}_{2}$ reduction [11,14-16]. These systems produce formate as the major product and $\mathrm{CO}$ as a minor product. The total quantum yield reaches $15 \%$. It is reported that water is needed for formation of formate, however the addition of a large amount of water decreases the efficiency of formate production. The addition of bpy increased the efficiency, probably to avoid the photolabilization of bpy from the $R u(b p y)_{3}{ }^{2+}$

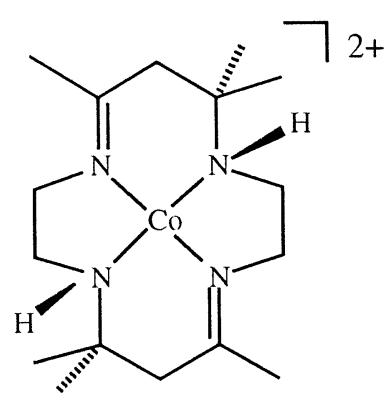

Scheme 1. $N$-rac-CoHMD ${ }^{2+}$. 


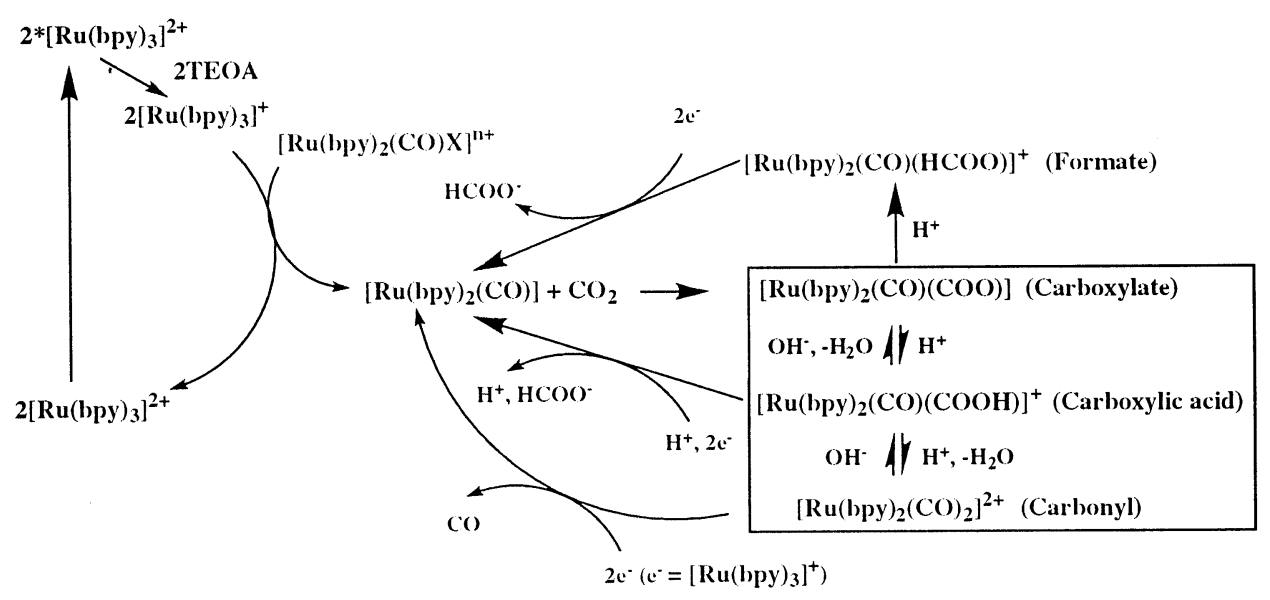

Scheme 2. Proposed mechanism for the $\mathrm{CO}_{2}$ reduction by $\mathrm{Ru}(\mathrm{bpy})_{2}(\mathrm{CO}) \mathrm{X}^{n+}$.

species. Tanaka et al. and Ziessel et al. reject $\left[\mathrm{Ru}(\mathrm{bpy})_{2}(\mathrm{CO})(\mathrm{H})\right]$ as an intermediate. This is contrary to what was found in electrochemical $\mathrm{CO}_{2}$ reduction by T.J. Meyer et al. [35]. The evidence Tanaka and Ziessel found indicates that $\left[\mathrm{Ru}(\mathrm{bpy})_{2}(\mathrm{CO})(\mathrm{Cl})\right]^{+}$and the hydride have almost the same activity. The proposed mechanism (Scheme 2) involves the reduction of $\left[\mathrm{Ru}(\mathrm{bpy})_{2}(\mathrm{CO}) \mathrm{Cl}\right]^{+}$by two electrons to produce $\left[\mathrm{Ru}(\mathrm{bpy})_{2}(\mathrm{CO})\right]$, which reacts with $\mathrm{CO}_{2}$ to form $\left[\mathrm{Ru}(\mathrm{bpy})_{2}(\mathrm{CO})(\mathrm{COO})\right] .\left[\mathrm{Ru}(\mathrm{bpy})_{2}(\mathrm{CO})(\mathrm{COO})\right]$ and $\left[\mathrm{Ru}(\mathrm{bpy})_{2}(\mathrm{CO})(\mathrm{COOH})\right]^{+}$are prepared by the addition of two and one $\mathrm{OH}^{-}$, respectively to $\left[\mathrm{Ru}(\mathrm{bpy})_{2}(\mathrm{CO})_{2}\right]^{+}[36-41]$. These are air stable species, and have been characterized by X-ray diffraction and various types of spectroscopy. In the photochemical system, it is proposed that the reverse reactions are taking place to form $\mathrm{CO}$ $[11,14-16]$. The production of formate is assumed to be involved in the isomerization of the carboxylate complex associated with protonation, or reduction of the carboxylic acid adduct associated with protonation. Unfortunately, Meyer et al. could not isolate the singly- or doubly-reduced hydride and its $\mathrm{CO}_{2}$ insertion product [35].

In the photochemical reduction of $\mathrm{CO}_{2}$, reduced metal catalysts, metal hydride complexes, metal formate complexes, and metallocarboxylates are postulated as intermediates. However, the kinetics and mechanisms of $\mathrm{CO}_{2}$ reduction still remain unclear in many cases. In order to design more efficient systems for the photochemical reduction of $\mathrm{CO}_{2}$ we need to understand factors controlling both the photochemical and the catalytic processes including photoexcitation and deactivation of the photosensitizer, precursor complex formation, charge transfer, energy transfer, back electron transfer, successor complex dissociation, interaction with $\mathrm{CO}_{2}$, bond formation and cleavage, and regeneration of the catalyst. Our research at BNL focuses on kinetic and mechanistic studies of photochemical $\mathrm{CO}_{2}$ reduction mediated by transition-metal complexes as catalysts as shown below. 


\section{3. $\mathrm{CO}_{2}$ reduction by cobalt macrocycles}

Previously we [30,42-48] and others [49] characterized the interaction of low-spin $\mathrm{d}^{8} \mathrm{~N}$-rac-Col${ }^{\mathrm{I}} \mathrm{HMD}^{+}$with $\mathrm{CO}_{2}$ in $\mathrm{CH}_{3} \mathrm{CN}$ and in $\mathrm{H}_{2} \mathrm{O}$. The $\mathrm{CO}_{2}$ binding constants in $\mathrm{CH}_{3} \mathrm{CN}$ [43] and in $\mathrm{H}_{2} \mathrm{O}$ [46] are $1.2 \times 10^{4}$ and $4.5 \times 10^{8} \mathrm{M}^{-1}$, respectively. The complex is thermochromic, being purple at room temperature and yellow at low temperature $\left(-100^{\circ} \mathrm{C}\right)$ with $\Delta H^{\circ}=-7.0 \mathrm{kcal} \mathrm{mol}^{-1}$ and $\Delta S^{\circ}=-27 \mathrm{cal} \mathrm{K}^{-1}$ $\mathrm{mol}^{-1}$ for Eq. (8) in $\mathrm{CH}_{3} \mathrm{CN}$ [44]. The spectra of $\mathrm{Co}^{\mathrm{I}} \mathrm{HMD}^{+},\left[\mathrm{CoHMD}\left(\mathrm{CO}_{2}\right)\right]^{+}$, and $\left[\mathrm{CoHMD}\left(\mathrm{CO}_{2}\right)\left(\mathrm{CH}_{3} \mathrm{CN}\right)\right]^{+}$are shown in Fig. 1. The pressure dependence of the equilibrium constant shows that increasing pressure shifts the equilibrium toward the six-coordinate species with an overall reaction volume $\Delta V^{\circ}=-17.7 \pm$ $1.0 \mathrm{ml} \mathrm{mol}-1$ at $15^{\circ} \mathrm{C}$ [48].

$$
\begin{aligned}
& \mathrm{CoHMD}^{+}+\mathrm{CO}_{2} \rightleftharpoons\left[\mathrm{CoHMD}\left(\mathrm{CO}_{2}\right)\right]^{+} \\
& {\left[\mathrm{CoHMD}\left(\mathrm{CO}_{2}\right)\right]^{+}+\mathrm{CH}_{3} \mathrm{CN} \rightleftharpoons\left[\mathrm{CoHMD}\left(\mathrm{CO}_{2}\right)\left(\mathrm{CH}_{3} \mathrm{CN}\right)\right]^{+}}
\end{aligned}
$$

The coordination number, geometry, and electronic properties have been studied using XANES [47]. The edge positions $\left(E_{0}\right)$ of the CoHMD complexes studied here are extremely sensitive to the oxidation state of the metal (Fig. 2). The edge energy, relative to $\mathrm{Co}^{\mathrm{II}} \mathrm{HMD}^{2+}$, decreases $(1 \mathrm{eV})$ upon reduction and increases $(2 \mathrm{eV})$ upon oxidation. The $1 \mathrm{~s}-4 \mathrm{p}_{\mathrm{z}}$ pre-edge peak, located ca. $6 \mathrm{eV}$ below the main edge in the XANES spectrum for $\mathrm{Co}^{\mathrm{II}} \mathrm{HMD}^{2+}$, is characteristic of a four-coordinate squareplanar geometry. The $E_{0}$ for $\left[\mathrm{CoHMD}\left(\mathrm{CO}_{2}\right)\right]^{+}$at room temperature is similar to that of $\mathrm{Co}^{\mathrm{II}} \mathrm{HMD}^{2+}\left(\Delta E_{0}=+0.2 \mathrm{eV}\right.$, which is within the reproducibility of the measurements), and is consistent with theoretical estimates that the bound $\mathrm{CO}_{2}$ receives 0.71 electrons mainly from the $\mathrm{Co}_{z}^{2}$ orbital [50,51]. The six-coordinate $\left[\mathrm{CoHMD}\left(\mathrm{CO}_{2}\right)\left(\mathrm{CH}_{3} \mathrm{CN}\right)\right]^{+}$species shows a $1.2 \mathrm{eV}$ shift towards $\mathrm{Co}(\mathrm{III})$ from

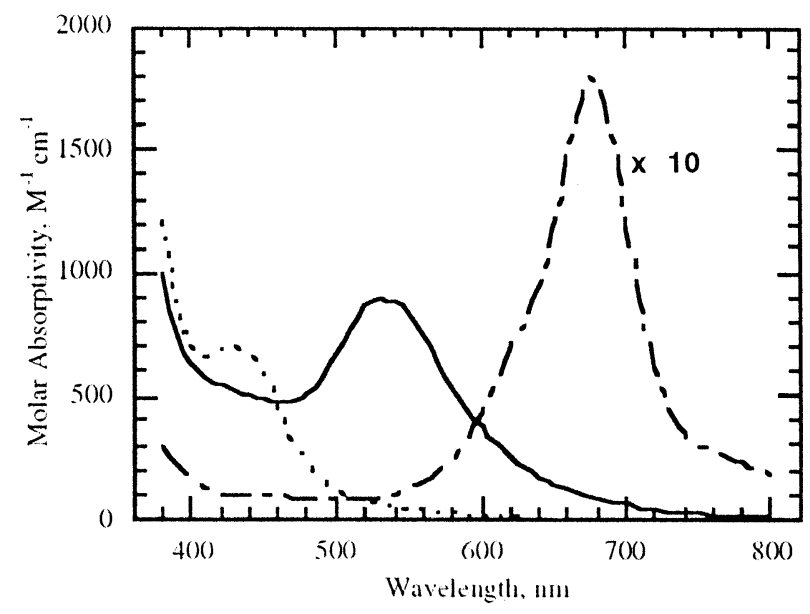

Fig. 1. UV-vis spectra of $\mathrm{Co}^{\mathrm{I}} \mathrm{HMD}^{+}(---), 5$-coordinate $\mathrm{CoHMD}\left(\mathrm{CO}_{2}\right)^{+}(-)$, and 6-coordinate $\left[\mathrm{Co}^{\mathrm{III}} \mathrm{HMD}\left(\mathrm{CO}_{2}{ }^{2-}\right)\left(\mathrm{CH}_{3} \mathrm{CN}\right)\right]^{+}(---)$in $\mathrm{CH}_{3} \mathrm{CN}$. 


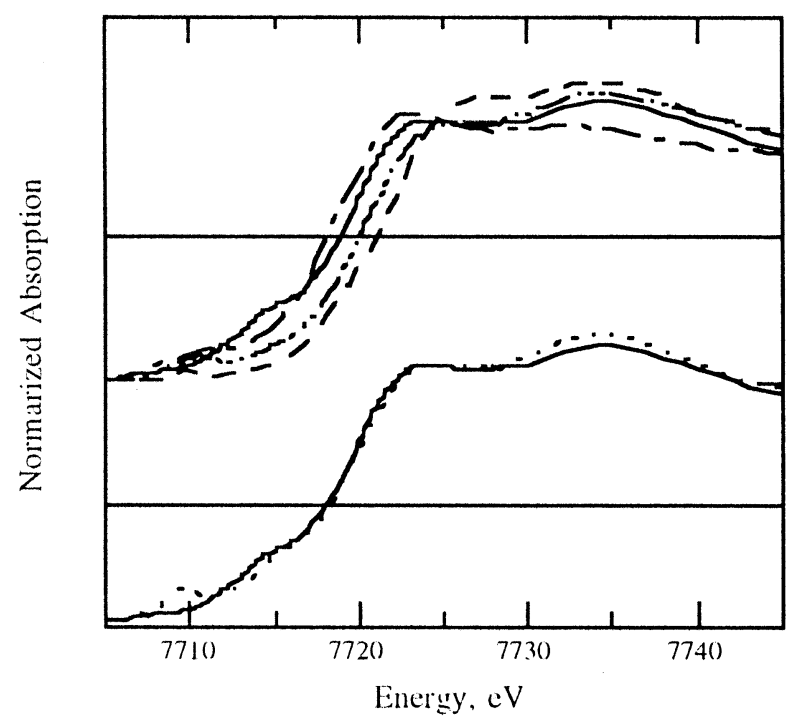

Fig. 2. XANES spectra for a series of CoHMD complexes. Top: $[\mathrm{CoHMD}(\mathrm{CO})]\left(\mathrm{ClO}_{4}\right)$ in $\mathrm{CH}_{3} \mathrm{CN}$ at room temperature (- - - ) [CoHMD $]\left(\mathrm{ClO}_{4}\right)_{2}$ in $\mathrm{CH}_{3} \mathrm{CN}$ at $150 \mathrm{~K}(-),\left[\mathrm{Co}^{\mathrm{II}} \mathrm{HMD}\left(\mathrm{CO}_{2}{ }^{2-}\right)\left(\mathrm{CH}_{3} \mathrm{CN}\right)\right]-$ $\left(\mathrm{ClO}_{4}\right)$ in $\mathrm{CH}_{3} \mathrm{CN}$ at $150 \mathrm{~K}(----)$, and $\left[\mathrm{Co}^{\mathrm{III}} \mathrm{HMD}\left(\mathrm{CO}_{3}\right)\right]\left(\mathrm{ClO}_{4}\right)$ in $\mathrm{H}_{2} \mathrm{O}$ at room temperature (- - -). Bottom: $\left[\mathrm{CoHMD}\left(\mathrm{CO}_{2}\right)\right]\left(\mathrm{ClO}_{4}\right)$ in $\mathrm{CH}_{3} \mathrm{CN}$ at room temperature (---) and $[\mathrm{CoHMD}]\left(\mathrm{ClO}_{4}\right)_{2}$ in $\mathrm{CH}_{3} \mathrm{CN}$ at $150 \mathrm{~K}(-)$.

$\mathrm{Co}^{\mathrm{II}} \mathrm{HMD}^{2+}$ and is interpreted as a $\mathrm{Co}(\mathrm{III})-\mathrm{CO}_{2}{ }^{2-}$ carboxylate complex. This assignment is consistent with the change of the asymmetric $v_{\mathrm{CO}_{2}}$ from $1706 \mathrm{~cm}^{-1}$ for $\left[\mathrm{CoHMD}\left(\mathrm{CO}_{2}\right)\right]^{+}$to $1544 \mathrm{~cm}^{-1}$ for $\left[\mathrm{CoHMD}\left(\mathrm{CO}_{2}\right)\left(\mathrm{CH}_{3} \mathrm{CN}\right)\right]^{+}$[45]. Although the $\mathrm{Co}(\mathrm{III})$ carboxylates have been postulated as intermediates in $\mathrm{CO}_{2}$ reduction and water-gas shift reactions, the XANES results provide the first unambiguous evidence that active metal catalysts, such as $\mathrm{Co}^{\mathrm{I}} \mathrm{HMD}^{+}$, can promote two-electron transfer to the bound $\mathrm{CO}_{2}$. This reversible intramolecular two-electron-transfer process, responsive to temperature and pressure changes, could be of fundamental importance to processes dealing with the reduction of $\mathrm{CO}_{2}$.

Cobalt macrocycles mediate electron transfer in the photoreduction of $\mathrm{CO}_{2}$ with $p$-terphenyl as a photosensitizer and a tertiary amine as a sacrificial electron donor in a 5:1 acetonitrile/methanol mixture, leading to efficient and selective formation of both $\mathrm{CO}$ and $\mathrm{HCO}_{2}^{-}$without producing much $\mathrm{H}_{2}$ [29]. The total quantum yield of $\mathrm{CO}$ and $\mathrm{HCO}_{2}^{-}$is 0.25 at $313 \mathrm{~nm}$ in the presence of TEOA and cocyclam ${ }^{3+}$ (see Table 1). The kinetics and mechanism of this system have been studied by continuous and flash photolysis techniques in the presence of TEA and CoHMD ${ }^{2+}$ [30]. Transient spectra provide evidence for the sequential formation of the $p$-terphenyl radical anion, the $\mathrm{Co}^{\mathrm{I}} \mathrm{HMD}^{+}$complex, the $\left[\mathrm{CoHMD}\left(\mathrm{CO}_{2}\right)\right]^{+}$complex and the $\left[\mathrm{S}-\mathrm{Co}^{\mathrm{III}} \mathrm{HMD}-\left(\mathrm{CO}_{2}{ }^{2-}\right)\right]^{+}$complex $(\mathrm{S}=$ solvent $)$ in the catalytic system.

$$
\mathrm{TP}+\mathrm{TEA}+h v \rightarrow \mathrm{TP}^{\cdot}-+\mathrm{TEA}^{\cdot}+
$$




$$
\begin{aligned}
& \mathrm{TP}^{\cdot}+\mathrm{Co}^{\mathrm{II}} \mathrm{HMD}^{2+} \rightarrow \mathrm{TP}+\mathrm{Co}^{\mathrm{I}} \mathrm{HMD}^{+} \\
& \mathrm{Co}^{\mathrm{I}} \mathrm{HMD}^{+}+\mathrm{CO}_{2} \rightleftharpoons \mathrm{CoHMD}\left(\mathrm{CO}_{2}\right)^{+} \\
& \mathrm{CoHMD}\left(\mathrm{CO}_{2}\right)^{+}+\mathrm{S} \rightleftharpoons\left[\mathrm{S}-\mathrm{Co}^{\mathrm{III}} \mathrm{HMD}_{-}\left(\mathrm{CO}_{2}^{2-}\right)\right]^{+} \\
& {\left[\mathrm{S}_{-} \mathrm{Co}^{\mathrm{II}} \mathrm{HMD}-\left(\mathrm{CO}_{2}^{2-}\right)\right]^{+}+\mathrm{HA} \rightleftharpoons\left[\mathrm{S}_{-} \mathrm{Co}^{\mathrm{III}} \mathrm{HMD}_{-}\left(\mathrm{COOH}^{-}\right)\right]^{2+}+\mathrm{A}^{-}} \\
& \quad \mathrm{HA}=\mathrm{HTEA}^{+}, \mathrm{MeOH}, \mathrm{H}_{2} \mathrm{O} \\
& {\left[\mathrm{S}_{-} \mathrm{Co}^{\mathrm{III}} \mathrm{HMD}-(\mathrm{COOH})^{-}\right]^{2+}+\mathrm{e}^{-} \rightarrow \mathrm{Co}^{\mathrm{II}} \mathrm{HMD}^{2+}+\mathrm{CO}+\mathrm{OH}^{-}} \\
& \quad \mathrm{e}^{-}=\mathrm{TP}^{-}, \mathrm{Co}^{\mathrm{I}} \mathrm{HMD}{ }^{+}, \mathrm{Et}_{2} \mathrm{NC}^{\bullet} \mathrm{HCH}_{3}
\end{aligned}
$$

The electron-transfer rate constant for the reaction of $p$-terphenyl radical anion with $\mathrm{Co}^{\mathrm{II}} \mathrm{HMD}^{2+}$ is $1.1 \times 10^{10} \mathrm{M}^{-1} \mathrm{~s}^{-1}$ and is probably diffusion controlled because of the large driving force (ca. 1.1 V). Flash photolysis studies yield a rate constant $1.7 \times 10^{8} \mathrm{M}^{-1} \mathrm{~s}^{-1}$ and an equilibrium constant $1.1 \times 10^{4} \mathrm{M}^{-1}$ for the binding of $\mathrm{CO}_{2}$ to $\mathrm{Co}^{\mathrm{I}} \mathrm{HMD}^{+}$in the catalytic system. These are consistent with the values previously obtained by conventional methods in acetonitrile. The $\mathrm{Co}^{\mathrm{I}} \mathrm{HMD}^{+}$produced reacts efficiently to form the $\mathrm{CO}_{2}$ adduct while the hydride formation is suppressed by limiting the amount of a proton source. Our study clearly shows evidence that the cobalt macrocycle provides two electrons to the $\mathrm{CO}_{2}$ moiety to produce a stable $\mathrm{SCo}{ }^{\mathrm{III}} \mathrm{HMD}\left(\mathrm{CO}_{2}{ }^{2-}\right)^{+}$species. The rate-determining step in the photocatalytic system seems to be the second electron transfer to $\mathrm{SCo}^{\mathrm{III}} \mathrm{HMD}\left(\mathrm{CO}_{2}{ }^{2-}\right)^{+}$, followed by a bond breaking step as shown in Eq. (14). The continuously formed $\mathrm{TP}^{-}$may be a source of the second electron.

\section{4. $\mathrm{CO}_{2}$ reduction by $\left[\mathrm{Ru}(\mathrm{bpy})_{2}(\mathrm{CO}) \mathrm{X}\right]^{n+}(\mathrm{X}=\mathrm{CO}, \mathrm{Cl}$, and $\mathrm{H})$}

DMF solutions containing $\mathrm{Ru}(\mathrm{bpy})_{3}{ }^{2+},\left[\mathrm{Ru}(\mathrm{bpy})_{2}(\mathrm{CO}) \mathrm{X}\right]^{n+}(\mathrm{X}=\mathrm{CO}, \mathrm{Cl}, \mathrm{H}$, etc.), and TEOA as an electron donor produce formate and $\mathrm{CO}$ from $\mathrm{CO}_{2}$ by photochemical processes [30]. We are characterizing the reaction of the reduced $\left[\mathrm{Ru}(\mathrm{bpy})_{2}(\mathrm{CO})_{2}\right]^{2+},\left[\mathrm{Ru}(\mathrm{bpy})_{2}(\mathrm{CO}) \mathrm{Cl}\right]^{+}$, or $\left[\mathrm{Ru}(\mathrm{bpy})_{2}(\mathrm{CO})(\mathrm{H})\right]^{+}$with $\mathrm{CO}_{2}$ in $\mathrm{CH}_{3} \mathrm{CN}$ to find out if $\left[\mathrm{Ru}(\mathrm{bpy})_{2}(\mathrm{CO})(\mathrm{COO})\right]$ is produced as proposed (see Scheme $2)$. It should be noted that $\mathrm{Ru}(\mathrm{bpy})_{3}^{+}$, produced by quenching the excited state of $\mathrm{Ru}(\mathrm{bpy})_{3}{ }^{2+}$ by TEOA, cannot reduce $\left[\mathrm{Ru}(\mathrm{bpy})_{2}(\mathrm{CO})(\mathrm{Cl})\right]^{+}$and $\left[\mathrm{Ru}(\mathrm{bpy})_{2}(\mathrm{CO})(\mathrm{H})\right]^{+}$to form the doubly- and singly-reduced species, respectively, as shown in Table 2. Instead, a species like $\left[\mathrm{Ru}(\mathrm{bpy})_{2}(\mathrm{CO})(\mathrm{S})\right]^{2+}(\mathrm{S}=$ solvent $)$ may be involved in photocatalytic $\mathrm{CO}_{2}$ systems.

The reduction potentials of $\mathrm{Ru}(\mathrm{bpy})_{2}(\mathrm{CO}) \mathrm{X}^{n+}$ species are summarized in Table 2. While the two-electron reduction wave in the cyclic voltammogram of $\left[\mathrm{Ru}(\mathrm{bpy})_{2}(\mathrm{CO})_{2}\right]^{2+}$ in $\mathrm{CH}_{3} \mathrm{CN}$ at $-1.0 \mathrm{~V}$ (vs SCE) is not affected by $\mathrm{CO}_{2}$, the second reduction wave of $\left[\mathrm{Ru}(\mathrm{bpy})_{2}(\mathrm{CO}) \mathrm{Cl}\right]^{+}$at $-1.55 \mathrm{~V}$ indicates an increase in current under $\mathrm{CO}_{2}$. The current depends on the electrolytes used. A very intense blue color develops with reduction of $\left[\mathrm{Ru}(\mathrm{bpy})_{2}(\mathrm{CO})_{2}\right]^{2+}$ by $\mathrm{Na}-\mathrm{Hg}$, which is indicative of a metal center reduction. The resulting solution does not react with 
Table 2

Reduction potentials (vs. SCE) of $\mathrm{Ru}(\mathrm{bpy})_{2}(\mathrm{CO}) \mathrm{X}^{n+}$ species

\begin{tabular}{llll}
\hline Complex & Solvent & Reduction potentials (V) & Ref. \\
\hline$\left[\mathrm{Ru}(\mathrm{bpy})_{3}\right]^{2+}$ & $\mathrm{CH}_{3} \mathrm{CN}$ & -1.34 & {$[52]$} \\
{$\left[\mathrm{Ru}(\mathrm{bpy})_{2}(\mathrm{CO})_{2}\right]^{2+}$} & $\mathrm{CH}_{3} \mathrm{CN}$ & $-1.0\left(2 \mathrm{e}^{-}\right)$ & This work \\
{$\left[\mathrm{Ru}(\mathrm{bpy})_{2}(\mathrm{CO})_{2}\right]^{2+}$} & $\mathrm{DMF}$ & $-0.95\left(2 \mathrm{e}^{-}\right)$ & {$[16]$} \\
{$\left[\mathrm{Ru}(\mathrm{bpy})_{2}(\mathrm{CO})(\mathrm{H})\right]^{+}$} & $\mathrm{CH}_{3} \mathrm{CN}$ & $-1.45,-1.65$ & This work, [35] \\
{$\left[\mathrm{Ru}(\mathrm{bpy})_{2}(\mathrm{CO})(\mathrm{Cl})\right]^{+}$} & $\mathrm{CH}_{3} \mathrm{CN}$ & $-1.33,-1.55$ & This work \\
{$\left[\mathrm{Ru}(\mathrm{bpy})_{2}(\mathrm{CO})(\mathrm{Cl})\right]^{+}$} & $\mathrm{DMF}^{+}$ & $-1.24,-1.48$ & {$[16]$} \\
{$\left[\mathrm{Ru}(\mathrm{bpy})_{2}(\mathrm{CO})\left(\mathrm{CH} \mathrm{CN}_{3} \mathrm{CN}\right]^{2+}\right.$} & $\mathrm{CH}_{3} \mathrm{CN}$ & $-1.10,-1.35$ & {$[35]$} \\
{$\left[\mathrm{Ru}(\mathrm{bpy})_{2}(\mathrm{CO})(\mathrm{OCOH})\right]^{+}$} & $\mathrm{CH}_{3} \mathrm{CN}$ & $-1.35,-1.52$ & {$[35]$} \\
{$\left[\mathrm{Ru}(\mathrm{bpy})_{2}(\mathrm{CO})(\mathrm{COO})\right]$} & $\mathrm{DMF}$ & $-1.30,-1.50$ & {$[15]$} \\
\hline
\end{tabular}

$\mathrm{CO}_{2}$. With or without $\mathrm{CO}_{2}$, a black species is precipitated and the solution becomes almost colorless. The species is $\left[\mathrm{Ru}(\mathrm{bpy})(\mathrm{CO})_{2}\right]_{n}$, produced by loss of a bpy ligand, as investigated by Ziessel et al. in the electrochemical $\mathrm{CO}_{2}$ reduction using the $\mathrm{Ru}$ mono- and bis-bpy carbonyl species on an electrode surface [53,54]. Interestingly, both Tanaka's and Ziessel's groups reported a decrease in catalytic activity with formation of a black precipitate during photoreduction of $\mathrm{CO}_{2}$. Therefore the proposed mechanism of $\mathrm{CO}$ production from $\left[\mathrm{Ru}(\mathrm{bpy})_{2}(\mathrm{CO})_{2}\right]^{2+}$ with two molecules of $\mathrm{Ru}(\mathrm{bpy})_{3}^{+}$serving as the electron source may not be involved in photochemical $\mathrm{CO}_{2}$ reduction.

The first reduction of $\left[\mathrm{Ru}(\mathrm{bpy})_{2}(\mathrm{CO}) \mathrm{Cl}\right]^{+}$seems to be bpy-centered. However, within a few minutes, two visible absorption features due to the bpy radical anion disappear, indicating intramolecular electron transfer is taking place to form $\left[\mathrm{Ru}^{\mathrm{I}}(\mathrm{bpy})_{2}(\mathrm{CO})\right]$ with loss of a $\mathrm{Cl}^{-}$ligand. The $\mathrm{Ru}(\mathrm{I})$ species does not react with $\mathrm{CO}_{2}$. The second reduction is the formation of a $\mathrm{Ru}(\mathrm{I})$ bpy radical, $\left[\mathrm{Ru}^{\mathrm{I}}(\mathrm{bpy})\left(\mathrm{bpy}^{-}\right)(\mathrm{CO})\right]$. Upon addition of $\mathrm{CO}_{2}$, the solution changes from reddish purple to brown and produces one or more species exhibiting IR stretching bands at $1966,1935,1252 \mathrm{~cm}^{-1}$. These stretching frequencies do not agree with published

Table 3

IR stretching frequencies for $\mathrm{Ru}$ complexes

\begin{tabular}{|c|c|c|c|c|}
\hline \multirow[t]{2}{*}{ Complex } & \multirow[t]{2}{*}{ Medium } & \multicolumn{2}{|c|}{ IR stretching frequencies, $\mathrm{cm}^{-1}$} & \multirow[t]{2}{*}{ Ref. } \\
\hline & & $v_{\mathrm{CO}}$ & $v_{\mathrm{CO}_{2}}$ & \\
\hline$\left[\mathrm{Ru}(\mathrm{bpy})_{2}(\mathrm{CO})\right]+\mathrm{CO}_{2}$ & $\begin{array}{l}\mathrm{CD}_{3} \mathrm{CN} \text { with } \\
\mathrm{Na}^{+}\end{array}$ & 1966,1935 & 1252 & This work \\
\hline$\left[\mathrm{Ru}(\mathrm{bpy})_{2}(\mathrm{CO})(\mathrm{COO})\right] \cdot 3 \mathrm{H}_{2} \mathrm{O}$ & $\mathrm{KBr}$ & 1911 & 1428 (weak), 1242 & {$[38]$} \\
\hline$\left[\mathrm{Ru}(\mathrm{bpy})_{2}(\mathrm{CO})(\mathrm{COO})\right]$ & $\begin{array}{l}\mathrm{CD}_{3} \mathrm{CN} \text { with } \\
\mathrm{Na}^{+}\end{array}$ & 1936 & 1252 & This work \\
\hline$\left[\mathrm{Ru}(\mathrm{bpy})_{2}(\mathrm{CO})(\mathrm{COO})\right]$ & $\begin{array}{l}\mathrm{CD}_{3} \mathrm{CN} \text { with } \\
\mathrm{Li}^{+}\end{array}$ & 1950 & 1283 & This work \\
\hline$\left[\mathrm{Ru}(\mathrm{bpy})_{2}(\mathrm{CO})(\mathrm{COOH})\right]^{+}$ & $\mathrm{CD}_{3} \mathrm{CN}$ & 1968 & & This work \\
\hline$\left[\left\{(\mathrm{bpy})_{2}(\mathrm{CO}) \mathrm{Ru}\right\}_{2}(\mathrm{COO})\right]^{2+}$ & $\mathrm{KCl}$ & 1954 & 1507,1176 & {$[58]$} \\
\hline
\end{tabular}


$\mathrm{KBr}$ data for $\left.\mathrm{Ru}(\mathrm{bpy})_{2}(\mathrm{CO})(\mathrm{COO})\right] \cdot 3 \mathrm{H}_{2} \mathrm{O}$ [37] (see Table 3). Although the carboxylate, $\left[\mathrm{Ru}(\mathrm{bpy})_{2}(\mathrm{CO})(\mathrm{COO})\right] \cdot 3 \mathrm{H}_{2} \mathrm{O}$ [37], is not soluble in $\mathrm{CH}_{3} \mathrm{CN}$, the addition of salts causes its dissolution. In the presence of $\mathrm{Li}^{+}$or $\mathrm{Na}^{+}$the carboxylate is slowly converted to the carboxylic acid in $\mathrm{CH}_{3} \mathrm{CN}$ with a trace amount of water. In the presence of $\mathrm{Mg}^{2+}$ the carboxylate is immediately converted to $\left[\mathrm{Ru}(\mathrm{bpy})_{2}(\mathrm{CO})_{2}\right]^{2+}$. The interaction of the bound $\mathrm{CO}_{2}$ of $\mathrm{Ru}(\mathrm{bpy})_{2}(\mathrm{CO})(\mathrm{COO})$ with a cation or proton shifts the $\mathrm{CO}$ and $\mathrm{CO}_{2}$ stretching frequencies dramatically as shown in Table 3. Such effects of alkali metal cation are not new. Cutler et al. recently found a similar trend on the IR shift of $\mathrm{CO}$ stretching using $\mathrm{FeCp} *(\mathrm{CO})(\mathrm{COO})^{-}\left(\mathrm{Cp}^{*}=1,2,3,4,5-\right.$ pentamethylcyclopenta-dienyl) [55]. Floriani [56] and Savéant [57] reported a large effect of alkali metal cations on the stability and reactivity of metal $\mathrm{CO}_{2}$ adducts such as $\mathrm{Co}(\mathrm{I})$ Salen $-\mathrm{CO}_{2}$ and $\mathrm{Fe}(0) \mathrm{TPP}-\mathrm{CO}_{2}$, respectively. The order of reactivity of these Lewis acid synergists is reported to be $\mathrm{Mg}^{2+}$ ca. $\mathrm{Ca}^{2+}>\mathrm{Ba}^{2+}>\mathrm{Li}^{+}>$ $\mathrm{Na}^{+}$from cyclic voltammetry of FeTPPCl with $\mathrm{CO}_{2}$. This result is consistent with our results for $\mathrm{Ru}(\mathrm{bpy})_{2}(\mathrm{CO})(\mathrm{COO})$ with alkali metals.

$\mathrm{Na}-\mathrm{Hg}$ was used as the reductant in our experiments of $\mathrm{CO}_{2}$ addition to the doubly reduced species in $\mathrm{CH}_{3} \mathrm{CN}$. Therefore, the resulting solution contains $\mathrm{Na}^{+}$, and the IR bands should correspond to those with $\mathrm{Na}^{+}$. In fact, two absorption peaks at 1935 and $1252 \mathrm{~cm}^{-1}$ are due to the carboxylate and a peak at $1966 \mathrm{~cm}^{-1}$ is due to the carboxylic acid adduct. The small differences in the IR stretching frequencies between this product (the first entry in Table 3) and authentic samples (the third and fifth entries) might be due to the $\mathrm{Na}^{+}$concentration differences in the solutions.

\section{Conclusion}

This article has summarized recent studies in our laboratory. $\mathrm{CoHMD}^{2+}$ has been used successfully as a catalyst for photochemical $\mathrm{CO}_{2}$ reduction because of the small $\mathrm{Co}^{\mathrm{II}} \mathrm{HMD}^{2+} / \mathrm{Co}^{\mathrm{I}} \mathrm{HMD}^{+}$reorganization energy, the fast $\mathrm{CO}_{2}$ binding to $\mathrm{Co}^{\mathrm{I}} \mathrm{HMD}^{+}\left(1.7 \times 10^{8} \mathrm{M}^{-1} \mathrm{~s}^{-1}\right)$ and the large $\mathrm{K}_{\mathrm{CO}_{2}}$. Our XANES results clearly indicate that active metal catalysts, such as $\mathrm{Co}^{\mathrm{I}} \mathrm{HMD}^{+}$, can promote two-electron transfer to the bound $\mathrm{CO}_{2}$ (reduce $\mathrm{CO}_{2}$ to $\mathrm{CO}_{2}{ }^{2-}$ ) and thereby facilitate reduction of $\mathrm{CO}_{2}$. The slow step in the photoreduction of $\mathrm{CO}_{2}$ is likely to be the $\mathrm{C}-\mathrm{O}$ bond rupture of the bound carboxylic acid, produced by protonation of [ $\mathrm{S}-$ $\left.\mathrm{Co}{ }^{\mathrm{III}} \mathrm{HMD}\left(\mathrm{CO}_{2}{ }^{2-}\right)\right]^{+}$, upon reaction with the electron donor. Unfortunately, the $\mathrm{UV}-$ vis transient spectrum of $\left[\mathrm{S}-\mathrm{Co}^{\mathrm{III}} \mathrm{HMD}\left(\mathrm{CO}_{2}{ }^{2-}\right)\right]^{+}$is too weak to permit the study of proton dependence, its disappearance and its further reactions.

The doubly reduced species $\left[\mathrm{Ru}^{\mathrm{I}}(\mathrm{bpy})\left(\mathrm{bpy}^{-}\right)(\mathrm{CO})\right]$ reacts with $\mathrm{CO}_{2}$ in $\mathrm{CH}_{3} \mathrm{CN}$. The reaction seems to produce $\left[\mathrm{Ru}(\mathrm{bpy})_{2}(\mathrm{CO})(\mathrm{COO})\right]$ together with $\left[\mathrm{Ru}(\mathrm{bpy})_{2}(\mathrm{CO})(\mathrm{COOH})\right]^{+}$. IR of $\left[\mathrm{Ru}(\mathrm{bpy})_{2}(\mathrm{CO})(\mathrm{COO})\right]$ shows a marked alkali metal cation dependence. Investigations of kinetics and mechanisms of photochemical reduction of $\mathrm{CO}_{2}$ continue with $\left[\mathrm{Ru}(\mathrm{bpy})_{2}(\mathrm{CO})(\mathrm{COO})\right]$ and $\left[\mathrm{Ru}(\mathrm{bpy})_{2}(\mathrm{CO}) \mathrm{H}\right]^{+}$. 


\section{Acknowledgements}

The author gratefully acknowledges the contributions to this work made by collaborators including Drs Norman Sutin, Carol Creutz, Bruce S. Brunschwig, Lars R. Furenlid, Mark W. Renner, and Tomoyuki Ogata, and Professors Shozo Yanagida, Rudi van Eldik and Koji Tanaka. This research was carried out at Brookhaven National Laboratory under contract DE-AC02-98CH10886 with the U.S. Department of Energy and supported by its Division of Chemical Sciences, Office of Basic Energy Sciences.

\section{References}

[1] T. Inui, M. Anpo, K. Izui, S. Yanagida, T. Yamaguchi (Eds.), Advances in Chemical Conversions for Mitigating Carbon Dioxide, vol. 114, Elsevier, Amsterdam, 1998.

[2] N. Sutin, C. Creutz, E. Fujita, Comments Inorg. Chem. 19 (1997) 67.

[3] J.-M. Lehn, R. Ziessel, Proc. Natl. Acad. Sci. USA 79 (1982) 701.

[4] F.R. Lemke, D.L. DeLaet, J. Gao, C.P. Kubiak, J. Am. Chem. Soc. 110 (1988) 6904.

[5] N.D. Silavwe, A.S. Goldman, R. Ritter, D.R. Tyler, Inorg. Chem. 28 (1989) 1231.

[6] D.A. Morgenstern, R.E. Wittrig, P.E. Fanwick, C.P. Kubiak, J. Am. Chem. Soc. 115 (1993) 6470.

[7] T.A. Hanna, A.M. Baranger, R.G. Bergman, J. Am. Chem. Soc. 117 (1995) 11363.

[8] P.-F. Fu, M.A. Khan, K.M. Nicholas, J. Organomet. Chem. 506 (1996) 49.

[9] D. Mandler, I. Willner, J. Am. Chem. Soc. 106 (1984) 5352.

[10] I. Willner, D. Mandler, A. Riklin, J. Chem. Soc. Chem. Commun. (1986) 1022.

[11] J.-M. Lehn, R. Ziessel, J. Organomet. Chem. 382 (1990) 157.

[12] N. Kitamura, S. Tazuke, Chem. Lett. (1983) 1109.

[13] R. Ziessel, J. Hawecker, J.-M. Lehn, Helv. Chim. Acta 69 (1986) 1065.

[14] H. Ishida, K. Tanaka, T. Tanaka, Chem. Lett. (1988) 339.

[15] H. Ishida, T. Terada, K. Tanaka, T. Tanaka, Inorg. Chem. 29 (1990) 905.

[16] H. Ishida, K. Tanaka, T. Tanaka, Organometallics 6 (1987) 181.

[17] A.T.A. Tinnemans, T.P.M. Koster, D.H.M.W. Thewissen, A. Mackor, Recl. Trav. Chim. Pays. Bas 103 (1984) 288.

[18] J.L. Grant, K. Goswami, L.O. Spreer, J.W. Otvos, M. Calvin, J. Chem. Soc. Dalton Trans (1987) 2105.

[19] C.A. Craig, L.O. Spreer, J.W. Otvos, M. Calvin, J. Phys. Chem. 94 (1990) 7957.

[20] E. Kimura, S. Wada, M. Shionoya, Y. Okazaki, Inorg. Chem. 33 (1994) 770.

[21] R. Maidan, I. Willner, J. Am. Chem. Soc. 108 (1986) 8100.

[22] I. Willner, R. Maidan, D. Mandler, H. Dürr, K. Zengerle, J. Am. Chem. Soc. 109 (1987) 6080.

[23] J. Hawecker, J.-M. Lehn, R. Ziessel, J. Chem. Soc. Chem. Commun. (1983) 536.

[24] J. Hawecker, J.-M. Lehn, R. Ziessel, Helv. Chim. Acta 69 (1986) 1990.

[25] C. Kutal, M.A. Weber, G. Ferraudi, D. Geiger, Organometallics 4 (1985) 2161.

[26] C. Kutal, A.J. Corbin, G. Ferraudi, Organometallics 6 (1987) 553.

[27] H. Hori, F.P.A. Johnson, K. Koike, O. Ishitani, T. Ibusuki, J. Photochem. Photobiol. A 96 (1996) 171.

[28] S. Matsuoka, K. Yamamoto, C. Pac, S. Yanagida, Chem. Lett. (1990) 2099.

[29] S. Matsuoka, K. Yamamoto, T. Ogata, M. Kusaba, N. Nakashima, E. Fujita, S. Yanagida, J. Am. Chem. Soc. 115 (1993) 601.

[30] T. Ogata, S. Yanagida, B.S. Brunschwig, E. Fujita, J. Am. Chem. Soc. 117 (1995) 6708.

[31] T. Ogata, Y. Yamamoto, Y. Wada, K. Murakoshi, M. Kusaba, N. Nakashima, A. Ishida, S. Takamuku, S. Yanagida, J. Phys. Chem. 99 (1995) 11916.

[32] J. Grodkowski, D. Behar, P. Neta, P. Hambright, J. Phys. Chem. A 101 (1997) 248. 
[33] D. Behar, et al., J. Phys. Chem. A 102 (1998) 2870.

[34] B. Fisher, R. Eisenberg, J. Am. Chem. Soc. 102 (1980) 7361.

[35] J.R. Pugh, M.R.M. Bruce, B.P. Sullivan, T.J. Meyer, Inorg. Chem. 30 (1991) 86.

[36] H. Ishida, K. Tanaka, M. Morimoto, T. Tanaka, Organometallics 5 (1986) 724.

[37] H. Tanaka, H. Nagao, S.-M. Peng, K. Tanaka, Organometallics 11 (1992) 1450.

[38] H. Tanaka, B.-C. Tzeng, H. Nagao, S.-M. Peng, K. Tanaka, Inorg. Chem. 32 (1993) 1508.

[39] K. Toyohara, K. Tsuge, K. Tanaka, Organometallics 14 (1995) 5099-5103.

[40] K. Toyohara, H. Nagao, T. Adachi, T. Yoshida, K. Tanaka, Chem. Lett. (1996) 27.

[41] H. Nakajima, K. Tsuge, K. Tanaka, Chem. Lett. (1997) 485.

[42] C. Creutz, H.A. Schwarz, J.F. Wishart, E. Fujita, N. Sutin, J. Am. Chem. Soc. 111 (1989) 1153.

[43] E. Fujita, D.J. Szalda, C. Creutz, N. Sutin, J. Am. Chem. Soc. 110 (1988) 4870.

[44] E. Fujita, C. Creutz, N. Sutin, D.J. Szalda, J. Am. Chem. Soc. 113 (1991) 343.

[45] E. Fujita, C. Creutz, N. Sutin, B.S. Brunschwig, Inorg. Chem. 32 (1993) 2657.

[46] C. Creutz, H.A. Schwarz, J.F. Wishart, E. Fujita, N. Sutin, J. Am. Chem. Soc. 113 (1991) 3361.

[47] E. Fujita, L.R. Furenlid, M.W. Renner, J. Am. Chem. Soc. 119 (1997) 4549.

[48] E. Fujita, R. van Eldik, Inorg. Chem. 37 (1998) 360.

[49] M.H. Schmidt, G.M. Miskelly, N.S. Lewis, J. Am. Chem. Soc. 112 (1990) 3420.

[50] S. Sakaki, A. Dedieu, J. Organomet. Chem. 314 (1986) C63.

[51] S. Sakaki, A. Dedieu, Inorg. Chem. 26 (1987) 3278.

[52] E. Fujita, S.J. Milder, B.S. Brunschwig, Inorg. Chem. 31 (1992) 2079.

[53] M.-N. Collomb-Dunand-Sauthier, A. Deronzier, R. Ziessel, J. Chem. Soc. Chem. Commun. (1994) 189.

[54] S. Chardon-Noblat, M.-N. Collomb-Dunand-Sauthier, A. Deronzier, R. Ziessel, D. Zsoldos, Inorg. Chem. 33 (1994) 4410.

[55] J.R. Pinkes, C.J. Masi, R. Chiulli, B.D. Steffey, A.R. Cutler, Inorg. Chem. 36 (1977) 70.

[56] S. Gambarotta, F. Arena, C. Floriani, P.F. Zanazzi, J. Am. Chem. Soc. 104 (1982) 5082.

[57] I. Bhugun, D. Lexa, J.-M. Savéant, J. Phys. Chem. 100 (1996) 19981.

[58] D.H. Gibson, Y. Ding, B.A. Sleadd, J.O. Franco, J.F. Richardson, M.S. Mashuta, J. Am. Chem. Soc. 118 (1996) 11984. 